\title{
Neoliberalism, subversion, and democracy in education
}

\author{
Neoliberalismo, subversión, y democracia \\ en educación
}

\section{Le néolibéralisme, subversion, et démocratie en education}

\author{
John Portelli \\ OISE, University of Toronto, Canada
}

\section{Christina Patricia Konecny}

OISE, University of Toronto, Canada

\begin{abstract}
This paper aims to further address what we regard as the detrimental influence that neoliberalism has had on any and all commitments to democratic ideals in educational settings. The argument is simply that a robust pluralism and cosmopolitanism in educational theory sits in tension with the neoliberalism of contemporary Western mass society. Our argument has two parts. First, we argue that the neoliberal hegemony of contemporary North American schooling is oppressive insofar as it negates and stifles any effort to enact democratic practices within classrooms settings, while simultaneously producing systemic inequities, dehumanization, and instrumentalization of teachers and students in schools. We then argue for an educational ethic of subversion, an ethic that we see as warranted, justified, and often necessary in the face of systems of schooling that are organized according to the logic of neoliberalism.
\end{abstract}

Key Words: neoliberalism; cosmopolitanism; symbolic inequities; educational ethic of subversions.

\section{RESUMEN}

Este artículo tiene por objetivo tratar lo que consideramos que es la influencia perjudicial que el neoliberalismo ha tenido en relación a cualquier compromiso con ideales democráticos en los escenarios educativos. El argumento es simplemente que un pluralismo y un cosmopolitismo 
robusto en la teoría educativa entran en tensión con el neoliberalismo de la sociedad occidental de masas contemporánea. Nuestro argumento tiene dos partes. En primer lugar argumentamos que la hegemonía neoliberal de la escolaridad norteamericana contemporánea es opresiva en tanto que niega y ahoga cualquier esfuerzo para poner en acción prácticas democráticas en las clases, al mismo tiempo que produce inequidad sistemática, deshumanización e instrumentalización de maestros y estudiantes en las escuelas. En segundo lugar argumentamos en favor de una ética educativa subversiva, una ética que vemos como justificada, y a menudo necesaria, frente a sistemas escolares que están organizados de acuerdo a la lógica del neoliberalismo.

Descriptores: neoliberalismo; cosmopolitismo; inequidades simbólicas; ética educativa de las subversiones.

\section{RÉSUMÉ}

Ce papier veut examiner l'influence du néolibéralisme dans les contextes éducatifs, influence que nous considérons nuisible à tout engagement aux idéaux démocratiques. L'argument est simplement qu'un pluralisme et cosmopolitisme robuste en théorie éducative est en tension avec le néolibéralisme de la société de masse occidentale. Notre argument est double; 1, nous soutenons que l'hégémonie néolibérale de l'instruction nord-américaine contemporaine est oppressive en tant qu'elle invalide et étouffe tout effort pour établir des pratiques démocratiques dans la salle de classe tout en produisant des inégalités injustes, la déshumanisation et l'instrumentalisation des enseignants et d'étudiants dans les écoles. 2, Nous argumentons en faveur d'une éthique éducative de subversion, éthique que nous voyons comme justifiée et souvent nécessaire en face de systèmes d'éducation organisés selon la logique du néolibéralisme.

Mots clés: le néolibéralisme; le cosmopolitisme; les iniquités symboliques; l'éthique éducative des subversions.

$I^{N}$ N RECENT YEARS, educational theory and philosophies of education have demonstrated a devotion to principles of cosmopolitanism, democracy, diversity, and pluralism within broadly conceived contexts of education. Yet, as Rosa Bruno-Jofré observes in her editorial message for the 2012 Queen's University Education Letter, for "many critical educational theorists, neither the liberal vision of a multicultural society and a multicultural education, nor communitarian visions of education [are] able to move forward with their arguments in light of the many sides of contemporary globalization." Liberal and communitarian visions of multiculturalism fall short due to their unfortunate inability to deal with difference in anything more than a topographical manner. While it is true that multicultural pluralism, at its core, embraces a recognition and appreciation of difference, it has little to offer when it comes to the ways in which membership in multiple social or cultural groups might intersect and shape a person's life. It also offers little guidance as to existing amongst, engaging with, or collaborating across difference in any genuine or substantial way. ${ }^{1}$ Bruno-Jofré (2012) goes on to note that "cosmopolitanism in its variants erupted in the educational scene inspiring critiques as well as renewed heuristic tools to explore avenues to deal with the inherent diversity of peoples experiences." Portelli's contribution to that same edition of the Education Letter, "The Challenges of Democratic Education in Cosmopolitan and Neo-liberal Times," tackled what are regarded as several pressing challenges to enacting a democratic model of education in today's schools. Namely, that neoliberal culture has oppressive, restricting, and stifling effects 
on contemporary education in general, and school settings in particular. This paper aims to further address what we regard as the detrimental influence that neoliberalism has had on any and all commitments to democratic ideals in educational settings.

The argument of this paper is simply that a robust pluralism and cosmopolitanism in educational theory - in contrast to liberal and communitarian views - sits in tension with the neoliberalism of contemporary Western mass society. Our argument has two parts. First, we argue that the neoliberal hegemony of contemporary North American schooling is oppressive insofar as it negates and stifles any effort to enact democratic practices within classrooms settings, while simultaneously producing systemic inequities, dehumanization, and instrumentalization of teachers and students in schools. We then argue for an educational ethic of subversion, an ethic that we see as warranted, justified, and often necessary in the face of systems of schooling that are organized according to the logic of neoliberalism. We contend that, unfortunately, it is often only through subversive means that educators are capable of creating classroom settings where students and teachers alike are able to be present as free, responsible, and whole human beings -that is, as political and intellectual beings who engage in genuine critical and quizzical inquiry and debate in a truly participatory and democratic fashion. In other words, we believe that it is often only by engaging in subversive acts and classroom practices that teachers and students can create a classroom space where democracy is truly an educational possibility.

\section{What is democracy? What is education?}

Democracy and its relationship to education is conceptualized in a variety of ways by many philosophers, educators, and theorists. As such, there are key distinctions that must be kept in mind while theorizing and enacting democratic practices in education, or while grappling with the relationship that does or ought to exist between democracy and education. For example, one must remain mindful of the fact that neither democracy nor education are monolithic, stable, or universal concepts, but are open and subject to multiple meanings. While education, for instance, may refer to teaching practices and learning opportunities that are instructional in nature and led in an explicit way by a teacher, it could instead perhaps involve student-directed learning environments where experiential, exploratory, practice-based learning is upheld. Likewise, education could be understood as something explicitly taught or learned, or as something that is learned implicitly through hidden, tacit, or inferred means of communication. For example, the cultural scenarios articulated by the arrangement of play spaces and particular representations of social power dynamics, gender, race, class, and ability presented to children in classrooms through cultural texts have been identified as the resources of a hidden curriculum present in school settings by theorists working in various disciplines, from sociology to philosophy of education. $^{2}$

Democracy is just as open to interpretation as education. There is first an important distinction to be made between democracy as an organizational rubric which 
defines how governments rule, and democracy as a way of life - that is, as an existential stance one takes up while engaging in the intersubjective relationships of a given community. The literature on democracy has identified this way of life by using differing terms: liberal democracy, marketized democracy, minimalist democracy, participatory democracy, deliberative democracy, cosmopolitan democracy, critical democracy, and strong democracy. ${ }^{3}$ Each of these terms is meant to evoke a variation in how democracy might be associated with a way of life. While it remains beyond the scope of this paper to examine the details of each of these conceptions of democracy, there are general distinctions that can be made to the common beliefs and practices involved with each. A broad distinction can be made, for instance, between conservative and progressive conceptions of democracy. Conservative conceptions tend to involve privatized, representative models of democracy, under which practical matters are handled by elected representatives within a majority rule decision-making system. They are reductive insofar as their democratic commitments pertain mostly to government rule, and regard settings that are not explicitly political as incompatible with or beyond the scope of application for the democratic principles. A key feature of conservative conceptions of democracy is that the interests of free market capitalism tend to have the final authority on social matters. The progressive vision of democracy, on the other hand, is defined by being public, critical, and participatory, and regards democracy as something much more fundamental and all-encompassing than merely a method of government. The progressive vision sees democracy as a set of commitments that can be enacted in domains that may seem unrelated to politics like work, labor, personal relationships, and - as in the case of this paper - the classroom.

In general, adherents of democracy would concede that democracy, however it is conceived, is constantly being reconstructed, or rethought, or rediscovered. ${ }^{4}$ The crucial question, then, becomes whether or not democracy is anything we wish it to be. While definitely allowing for the reimagining of democracy as social conditions change, we contend that such reimagining does not imply that there are no core qualities associated with democracy that we cannot give up without exhibiting undemocratic values or actions. There is a democratic soul, so to speak. One of the central litmus tests of any model for democracy is how it deals with differences. While the authoritarian crushes disagreements and differences and the soft liberal puts disagreements aside (as he or she believes they are all fine, as long as they do not interfere with the rights of the individual), the genuine democrat acknowledges the differences, does not shy away from disagreements, and rather than crushing or hiding disagreements, engages meaningfully with them. After all, democracy is not a way of life that promotes standardization or one-size-fits-all solutions to social problems. On the contrary, at the heart of any commitment to democracy is the belief that incorporating and working across difference is fundamentally valuable, that all citizens capable of participating in social governance do so equally, whether by proxy, vote, dialogue, debate, or critique. The crucible that democracy accepts, of its very nature, is to deal with substantive differences in a humane manner. This fundamental aspect of democracy is what provides a direct link to cosmopolitanism and 
pluralism, since it "calls for citizens to who can respond in ways consistent with the inherent dignity of human beings" (Snauwaert, 2002, p. 11) while exposing citizens to the "diverse perspectives of others" through which one's own views are challenged (Snauwaert, 2009, p. 101).

There are also variants of how theorists conceive of whatever relationship does or ought to exist between democracy and education. Some scholars take up critical and participatory forms democracy in order to critique the institutionalized, incorporated, and bureaucratic organizational system of modern schooling. Others view the educational context as a place of political possibility, suggesting that democracy in the classroom is essential to social justice, both in the classroom and beyond it. ${ }^{5}$ We embrace both conceptions of the relationship between democracy and education. We believe that democracy is a concept that is capacious enough to both critique the current neoliberal system of education and school while also offering a model that can assist educators who wish to create classroom spaces of genuine intersubjectivity and pluralism - spaces that do not negate the full personhood of those who populate them, nor silence those who speak within them.

Finally, there is an important difference between educating for democracy - which implies a causal and uni-directional relationship between teaching, learning, and the reproduction of a democratic society - and democracy in education - which necessarily involves enacting democratic principles in the classroom. Educating for democracy is explicitly intended to facilitate the development of the skills necessary for participating in a democratic society, but may not be carried out in a democratic fashion. Democracy in education, on the other hand, enacts democratic practices in the classroom, making education into a democratic process rather than a means toward a future democracy. There is no guarantee that democracy in education will result in citizens who support democratic schemas of social government.

\section{Neoliberalism in today's schools}

Despite the prevalence of democracy in the humanities throughout the twentieth and twenty-first centuries, a neoliberal culture dominates the 'Western world,' and is now, by means of globalization, colonizing other 'non-Western' worlds. The culture of neoliberalism militates against the growth of any robust democratic culture. As nineteenth-century schools of liberal individualism and negative rights and freedoms shifted to the excessive individualism of so-called free-market capitalism, incessant competition, social atomism, reductionism, presumed neutrality and objectivity, narrow utility, and accountability came to dominate the North American way of life. Henry Giroux astutely notes that the disastrous effects of neoliberalism have affected all public spheres of social life. He writes:

neoliberal ideology, with its merciless emphasis on deregulation and privatization, has found its material expression in an all-out attack on democratic values and social relations - particularly those spheres where such values are 
learned and take root. Public services such as health care, childcare, public assistance, education, and transportation are now subject to the rules of the market. Forsaking the public good for the private good and representing the needs of the corporate and private sector as the only source of sound investment... (Giroux \& Giroux, 2006, p. 24)

The neoliberal reorganization of social life hollows out social resources in the interest of capital gain, and public education is particularly vulnerable to such a reformation of public life. A domineering form of neoliberalism has transformed the practical organization of schooling. This can be observed in the rampant instrumentalization of teaching and learning, the contemporary cult of effectiveness and efficiency, and the shift toward standardized models of curriculum saturated by the demand to meet district quotas and perform well on regional tests. Schools, particularly in the United States, ${ }^{6}$ are now scrutinized according to a cost-savings model of resource allocation and held responsible for the production of future citizens of free market capitalism. As schools become incorporated - resembling private businesses more and more, and losing their status and function as a public resource open to all - both the nature of the school in relation to society and the particular micro-level details of classroom life change drastically. At the social level, it is only by performing well 'on paper' and scoring well on standardized tests that schools are able to access the resources on which their programs depend. ${ }^{7}$ Schools that do not meet the regional standards on test scores are denied already limited funding, resulting in residential segregation, inequities in the quality of available education, inadequate access to public services, and cyclical poverty (Giroux \& Giroux, 2006). Moreover, at the micro level of individual classrooms, teachers are bombarded by standardized lesson plans that leave little room for exploratory learning within the community of the classroom. Students are categorized according to achievement levels, and teachers are required to incessantly carry out bureaucratic measures of surveillance in the form of constant record-keeping and reporting.

School systems organized according to the results-based logic of neoliberalism instrumentalize teachers, dehumanize students, and make the classroom into a space of performance and efficiency, thereby denying more robust educational experiences as well as the communal and cultural aspects of schooling - let alone permitting any genuine engagement with social problems, political issues, or cultural critique. The neoliberal ethos of contemporary schooling not only negates the space of democratic possibility, but also enforces its own agenda by means of sanctions and punishments in the name of accountability and results-based recognition. Giroux (2006) likewise contends that the contemporary state of public school is at odds with a commitment to democracy in the classroom, arguing that "as democracy becomes a burden under the reign of neoliberalism, civic discourse disappears or is subsumed by a growing authoritarianism in which politics is translated into unquestioning allegiance to authority" (p. 27).

In short, the way of life that has emerged from neoliberalism is not consistent with the soul of democracy, for it has put aside the power of the humanities (Nussbaum, 
2010) and thoughtful social sciences in favor of privileging standardization and promoting empirical evidence to the exclusion of the domains of the moral, critical, spiritual, artistic, and philosophical. Evidence has been reduced to only one kind, empirical, and no other forms of evidence qualify as such. Within such a context, enacting democratic education has become an onerous task - especially if, as it should be, it is based on equity rather than simply equality of opportunity, diversity and difference rather than conformity and normalization, substantive and controversial issues rather than cold procedures and facts, taking a fair stand rather than pretending to be neutral and reproducing current injustices, and finally, embracing social activism rather than simply deliberating and discussing.

\section{Democracy in education}

A school principal once admonished one of us for how unrealistic democratic practices were in typical school settings, chiding that he could not convene the entire staff and student body to vote on every decision he has to make. Unfortunately, this naïve conception of democracy, actually quite common in popular discourse, is not what we mean by democracy as a way of life. Simply stated, democratic education is an education that takes democracy and its associated values seriously in both theory and practice. Embracing democracy as an educational ideal means that we believe the struggle to achieve democracy and the beliefs, conditions, and practices that go along with it is worthwhile. Democracy substantively deals with how human beings ought to relate to one another, proposing, as Dewey (1938) has argued, a way of life that is most humane. It is crucial here to note that when we talk about democratic education, we are not referring to an education that follows so-called democratic governance but to that democratic way of life mentioned in the section above, a way of life that we believe needs to be enacted in educational institutions despite the dominant presence and domineering effects of neoliberalism in today's schools.

Regardless of the particular conception of democracy that one embraces, it remains both a moral and political ideal. Ideals are that toward which one strives, not fixed end points or destinations to be reached. As an ideal, democracy can never be fully achieved or finished. This is the very nature of ideals. But fully actualizing an ideal is not the point. The meaning of an ideal resides in the imperfect attempts to make idealized principles a worldly reality - attempts that, with each repetition and revision, bring the world in which human beings live closer and closer to an unreachable perfection. Striving toward an ideal, while never attainable, makes the world in which that striving takes place better.

\section{Subversion of neoliberal systems of schooling}

A democratic education that honors a robust democracy has to consciously and, at times, subversively challenge neoliberal practices in educational institutions, including 
universities - particularly when those institutions negate the personhood, human rights, and lived realities of the teachers and students who inhabit them. The neoliberal culture of contemporary school instrumentalizes teachers, making them into nothing more than figures of authority to administer lessons and keep detailed records of their students' academic performance. It dehumanizes students, who are required to be present in schools, as members of an educational system whose sole responsibility is to get good grades. Within this context, neither teachers nor students are able to exist in the classroom as full persons who live communally connected lives. We believe that a system of schooling that instrumentalizes and dehumanizes teachers and students in this fashion is oppressive, and that subversion is a justifiable educational ethic to take up in such a situation.

In a forthcoming paper on the ethical implications of subversion, Portelli points out that, while subversion tends to carry negative connotations in everyday discourse, etymologically the word is rooted in the Latin words sub (under) and vertere (to turn around/over). He points out that since the word subversion means 'to turn or change from the bottom or foundation' [it] is not necessarily vicious. In other words, subversion means to change from below, to turn around or redirect from underneath, and is not necessarily a negative, aggressive, or vindictive act. It could, alternatively, be that through subversive acts, something harmful or negative is undone. When it comes to relations of social power, oppressive government institutions or policies, or systemic structures that disenfranchise particular groups of people, effective subversion is an undertaking that can have especially positive results.

In Judith Butler's Gender Trouble: Feminism and the Subversion of Identity (1999), she astutely notes that subversive acts occur within systems of negation and erasure in order to open up a space of political possibility. In systems of negation or erasure for particular groups of people, that possibility might simply be intelligible existence. She explains that "one might wonder what use 'opening up possibilities' finally is, but no one who has understood what it is to live in the social world as what is 'impossible,' illegible, unrealizable, unreal, and illegitimate is likely to pose that question" (p. xiii). Butler's point is that social relations of power function to both produce and perpetuate cultural narratives that designate which identities are legitimate and livable for human beings. It's not that these 'impossible categories' do not exist - they do - but that our world is organized in ways that make living out one's life in certain ways impossible.

In a system of schooling that instrumentalizes and dehumanizes teachers and students, simply creating a space where personhood can be asserted may count as a subversive act. Portelli (forthcoming) notes, following Mills, that

some people's basic affirmations of personhood or attempts at self-governance are often represented as 'subversive' in oppressive power structures... In an education system that effectively erases certain student's histories, identities, and needs - and fails to recognize or address the systemic and ideological causes of these erasures... subtle or sneaky assertions of personhood, of their 'thereness,' count as subversion. (p. 5) 
We believe that in such cases, subversion is justified and warranted.

\section{Conclusion}

Based on insights from research projects conducted in Canada, we know that the general democratic spirit in education has been eroded. ${ }^{8}$ However, we have encountered courageous educators, both teachers and school principals, who are willing to struggle for the democratic spirit in education to benefit students who have traditionally been marginalized, especially as the result of a system-wide deficit mentality.

Democracy in education calls for a curriculum that takes life seriously in its entirety, not just those aspects that continue to privilege certain groups. Regardless of which particular progressive conception of democratic education one takes up, critical and democratic pedagogy in "its innumerable variations reflects both a shared belief in education as a moral and political practice and a recognition that its value should be judged in terms of how it prepares students to engage in a common struggle for deepening the possibilities of autonomy, critical thought, and a substantive democracy" (Giroux, 2006).

Simply focusing on the so-called "achievement gap," without questioning the onesize-fits-all criteria used to determine achievement, does not ensure the revitalization of the democratic spirit. Life and success come in different forms. Democracy, of its very nature, aims to open up possibilities for all forms of life and success. Until all those involved in educational policy realize the democratic fact of possibilities, rather than standardization, we have no option but to continue to rely on subversion as a means of creating equity and social justice in education.

\section{Notes}

1. There is an important distinction between liberal views of multicultural pluralism and communitarian notions of the concept. Whereas liberal theories see democratic communities as the result of voluntary and mutually benefiting agreements between individuals who exist prior to any given social system, the communitarian believes that there is no pre-social human being, that the interpersonal and communal relationships of a person shape who a person is in a fundamental way. Liberal democratic theory places an ultimate value on social arrangements that are formed and justified by the benefits of group membership, whereas communitarianism places an ultimate value on relationality, kinship, and social connection. For an in-depth account of the liberal view, see: Kymlicka, W. (1995). Multicultural citizenship: A liberal view of minority rights. Oxford, England: Oxford University Press, p. 287. Iris Marion Young, on the other hand, offers a critique of liberal democratic practices and defends communitarian models of democracy; see, for example: Young, I. M. (1990). Justice and the politics of difference. Princeton, NJ: Princeton University Press.

2. For more on the hidden curriculum of school settings see: Best, R. (1983). Wéve all 
got scars: What boys and girls learn in elementary school. Bloomington, IN: Indiana University Press; Thorne, B. (1993). Gender play: Girls and boys in school. New Brunswick, NJ: Rutgers University Press; Weitzman, L. J. (1979). Sex role socialization: A focus on women. 1st ed. Palo Alto, CA: Mayfield Pub. Co.; Corsaro, W. A. (1983). Script recognition, articulation and expansion in children's role play. Discourse Processes, 6(1); Corsaro, W. A. (2005). The sociology of childhood (Sociology for a New Century series). 2nd ed. Thousand Oaks, CA: Pine Forge Press.

3. See, for example: Held, D. (2006). Models of Democracy. Palo Alto, CA: Stanford University Press; Portelli, J. (2001). Democracy in education: Beyond the conservative or progressive stances. In W. Hare \& J. P. Portelli (Eds.), Philosophy of education: Introductory readings (pp. 279-294). Calgary, Canada: Detselig.

4. See: Dewey, J. (1916). Democracy and education. New York, NY: Free Press; Ermarth, E. D. (Ed.). (2007). Rewriting democracy: Cultural politics in postmodernity. Aldershot, England: Ashgate; McDonnell, L. M., Timpane, P. M., \& Benjamin, R. (Eds.). (2000). Rediscovering the democratic purpose of education. Lawrence, KS: University of Kansas Press.

5. See, for example, Giroux, H. A. (2009). Democracy's nemesis: The rise of the corporate university. Cultural Studies - Critical Methodologies, 9(5), 669-695; Greene, M. (1986). In search of a critical pedagogy. Harvard Educational Review, 56(4), 427-442; Westheimer, J. (2011). Confronting power: Success isn't everything - but it's not nothing either. Democracy and Education, 19(1), article 10.

6. While the issues we discuss here regarding the privatization and corporatization of schools are most prevalent in the United States, they remain important forewarnings for the Canadian school system. Canadian universities have undergone a massive structural reorganization during the last two decades that has made them function more like private corporations rather than public institutions. In the United States, primary and secondary schools followed the incorporation of Universities, and we believe that Canada will demonstrate a similar shift.

7. It is important to note that this is not the case in Canada. On the contrary, troubled schools receive more funding in order to supplement particular program needs. These extra funds, however, are usually put toward programs that will assure test scores - the assumption being that if you do well on tests, you are intelligent. There is evidence that suggests, however, that certain intellectual skills have been suffering under this formulaic and instrumentalized model of teaching and learning. Students no longer exhibit critical thinking, an enjoyment of literature or the arts, or engagement in intellectual thought, but are now only interested in doing well on tests.

8. "Investing in equity," P.I.: John P. Portelli (Co-investigators: Reva Joshee \& Herveen Singh); "Educational equity and inclusion in neoliberal times: Policy webs and school practice," SSHRC, P.I.: John P. Portelli (Co-investigators: Reva Joshee, Jim Ryan, Brenda Spencer, \& Ann Vibert); "Pedagogies at risk: Social justice teaching and accountability discourses," SSHRC, P.I.: Ann Vibert (Co-investigators: John P. Portelli \& Carolyn Shields); "The validity of the Ontario Teacher Qualifying Test: Stakeholders' perspectives,” SSHRC, P.I.: John P. Portelli (Co-investigators: Patrick Solomon \& Donatille Mujawamarija); “Toward an equitable education: Diversity, poverty, and students at risk,” P.I.: John P. Portelli (Co-investigators: Ann Vibert \& Carolyn Shields); "Student engagement, democratic practices, and curriculum of life,” Connaught Grant, University of Toronto, P.I.: John P. Portelli. More information about these projects available from: www.john-peter-portelli.com. 


\section{References}

Bruno-Jofré, R. (2012). From pluralism to cosmopolitanism. Education Letter (Fall/Winter). Kingston, Canada: Queen's University, Faculty of Education.

Butler, J. (1990). Gender trouble: Feminism and the subversion of identity. New York, NY: Routledge.

Dewey, J. (1938). Experience and education. New York, NY: Macmillan.

Giroux, H. A., \& Giroux, S. S. (2006). Challenging neoliberalism's New World Order: The promise of critical pedagogy. Cultural Studies - Critical Methodologies, 6(1), 21-32.

Nussbaum, M. C. (2010). Not for profit: Why democracy needs the humanities. Princeton, NJ: Princeton University Press.

Portelli, J. (2012). The challenges of democratic education in cosmopolitan and neo-liberal times. Education Letter (Fall/Winter). Kingston, Canada: Queen's University, Faculty of Education.

Snauwaert, D. T. (2002). Cosmopolitan democracy and democratic education. Current Issues in Comparative Education, 42(2), 5-15.

Snauwaert, D. T. (2009). Human rights and cosmopolitan democratic education. Philosophical Studies in Education, 40, 94-103. 